\title{
Transforming growth factor beta1 (TGF-ß1) levels in a rat model of induced pleural empyema ${ }^{1}$
}

Samanta Sarmento da Silva', Guilherme Eckert Peterson', Sérgio Luis Amantéa", Patrícia Miorelli"', Jane Maria Ulbrich"v, Eliane Roeschv, Paulo Roberto Sanchesvi, Jose Carlos Fragavil

'Fellow Master degree, Postgraduate Program in Surgical Sciences, School of Medicine, Universidade Federal do Rio Grande do Sul (UFRGS), Porto Alegre-RS, Brazil. Scientific, intellectual, conception and design of the study; technical procedures; acquisition, analysis and interpretation of data; manuscript preparation; final approval

"Associate Professor, Pediatric Department, Universidade Federal de Ciências da Saúde de Porto Alegre (UFCSPA), Brazil. Scientific, intellectual, conception and design of the study; analysis and interpretation of data; critical revision; final approval.

I"'Graduate student, School of Medicine, UFRGS, Porto Alegre-RS, Brazil. Acquisition of data, technical procedures.

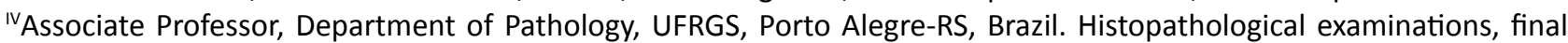
approval.

${ }^{B}$ Biochemist, Division of Microbiology and Molecular Biology, Clinical Pathology Service, Hospital de Clínicas de Porto Alegre (HCPA), Brazil. Technical procedures, final approval.

${ }^{V I} \mathrm{PhD}$, Biomedical/Medical Engineering, HCPA, Porto Alegre-RS, Brazil. Scientific and intellectual content of the study, final approval.

VIIFull Professor, and Chairman, Department of Surgery, UFRGS, Porto Alegre-RS, Brazil. Scientific, intellectual, conception and design of the study; analysis and interpretation of data; critical revision; final approval.

\section{Abstract}

Purpose: To evaluate the concentration of transforming growth factor beta 1 (TGFB1) levels in a rat pleural effusion obtained by inoculation of intrapleural bacteria or turpentine through thoracentesis.

Methods: Thirty-Nine Wistar rats were divided into three groups: Staphylococcus aureus (SA, $n=17)$; Streptococcus pneumoniae (SP, $n=12)$; and turpentine (control, $n=10)$. Pleural fluid was collected through ultrasound-guided thoracentesis 12 h, 24 h, and 36 h after instillation of bacteria or turpentine. Levels of TGFB1 were measured in pleural fluid.

Results: At $12 \mathrm{~h}$, mean TGFB1concentrations were $5.3450 \mathrm{pg} / \mathrm{mL}$ in the SA group, $5.3449 \mathrm{pg} /$ $\mathrm{mL}$ in the SP group, and $5.3450 \mathrm{pg} / \mathrm{mL}$ in controls. At $24 \mathrm{~h}$, they were $4.6700 \mathrm{pg} / \mathrm{mL}$ in the SA group, $4.6700 \mathrm{pg} / \mathrm{mL}$ in the SP group, and $4.6700 \mathrm{pg} / \mathrm{mL}$ in controls. At $36 \mathrm{~h}$, they were $4.6699 \mathrm{pg} / \mathrm{mL}$ in the SA group and in control. No difference was observed among the groups in mean TGFB1concentration ( $p=0.12$ ); however, a significant intragroup reduction in mean TGFB1 was observed between 12 and $24 \mathrm{~h}(\mathrm{p}<0.01)$.

Conclusion: The transforming growth factor beta 1 concentrations were not useful as a diagnostic tool or an early marker of infected pleural effusion.

Key words: Empyema, Pleural. Cytokines. Transforming Growth Factor beta1. Rats. 


\section{Introduction}

Complicated parapneumonic pleural effusion (CPPE) remains a challenging problem ${ }^{1}$, and current literature on the subject emphasizes the importance of early diagnosis ${ }^{2,3}$. Thus, early diagnosis and treatment are believed to be crucial to reduce CPPE morbidity and mortality in both adult and pediatric populations.

Cytokines have been identified as promising early markers of parapneumonic effusion and empyema. Some studies have shown that transforming growth factor beta 1 (TGF-ß1), a multifunctional cytokine, is associated with formation of fibrin and pleural fluid loculation, possibly indicating poorer prognosis and need for more aggressive treatment of pleural effusion ${ }^{4,5}$.

Due to the difficulty in designing prospective population-based studies on CPPE and controlled studies for diagnostic evaluation and testing of therapeutic strategies, experimental animal models have been playing an important role in the search for biological markers of pleural infection and empyema. Most experimental models of pleural effusion or empyema described in the literature have employed pigs ${ }^{6-8}$ or rabbits ${ }^{9,10}$. However, a new rat model of empyema has been successfully developed ${ }^{11,12}$, with greater reproducibility and lower cost and housing infrastructure than those of rabbits or pigs.

The present experiment was developed to study the behavior of TGF-ß1 levels and concentration in pleural effusion over time, after induction of infected and sterile pleural effusion in rats by inoculation of bacteria or turpentine through thoracentesis with intrapleural pressure monitoring.

\section{Methods}

After approval from the Institutional
Review Board, thirty nine male Wistar rats, mean weigh $414 \mathrm{~g}$ (290 to $546 \mathrm{~g}$ ), were divided into three different groups: 17 animals were inoculated with $0.1 \mathrm{~mL}$ brain-heart infusion containing Staphylococcus aureus at a concentration of $10^{10}$ colony forming units (CFU)/mL (SA group); 12 animals were inoculated with $0.05 \mathrm{~mL}$ brain-heart infusion containing Streptococcus pneumoniae at a concentration of $10^{10} \mathrm{CFU} / \mathrm{mL}$ (SP group); and $0.2 \mathrm{~mL}$ turpentine was administered to 10 control animals (Group C). The handling of animals followed institutional and national guidelines ${ }^{13}$.

After mask induction of anesthesia with isoflurane and intraperitoneal administration of tramadol $(0.05 \mathrm{~mL} / 100 \mathrm{~g})$ for pain control, each animal was positioned in left lateral decubitus for removal of hair on the right hemithorax, followed by skin disinfection with chlorhexidine solution. Bacteria or turpentine were instilled using a venous access catheter (VAC) inserted through the fourth right intercostal space. The position of the VAC inside the pleural space was ascertained before bacterial injection using a pressure meter (oscillometer). This device was connected to the VAC and capable of determining the moment when the catheter enters the pleural cavity by detecting the resulting fall in pressure. After making sure that the catheter was inside the pleural space, Staphylococcus aureus, Streptococcus pneumonia, or turpentine were injected, with continued pressure monitoring using the oscillometer. Following the procedure, the animals were monitored and a second dose of tramadol was administered if necessary.

After $12 \mathrm{~h}$ the animals were again anesthetized with isoflurane and treated with intraperitoneal tramadol for pain control. Chest ultrasound (US) was performed to confirm the presence of pleural effusion and guide thoracentesis for fluid collection (Figure 
1). The collected fluid was divided into three equal aliquots and stored in Eppendorf tubes for dosing of proteins, lactate dehydrogenase (LDH), glucose, and Gram staining. The remaining aliquots were stored at $-80^{\circ} \mathrm{C}$ for determination of TGF-ß1 levels (baseline). The same procedure was performed $24 \mathrm{~h}$ and 36 $\mathrm{h}$ after inoculation. The animals were then euthanized with a lethal dose of ketamine/ xylazine.

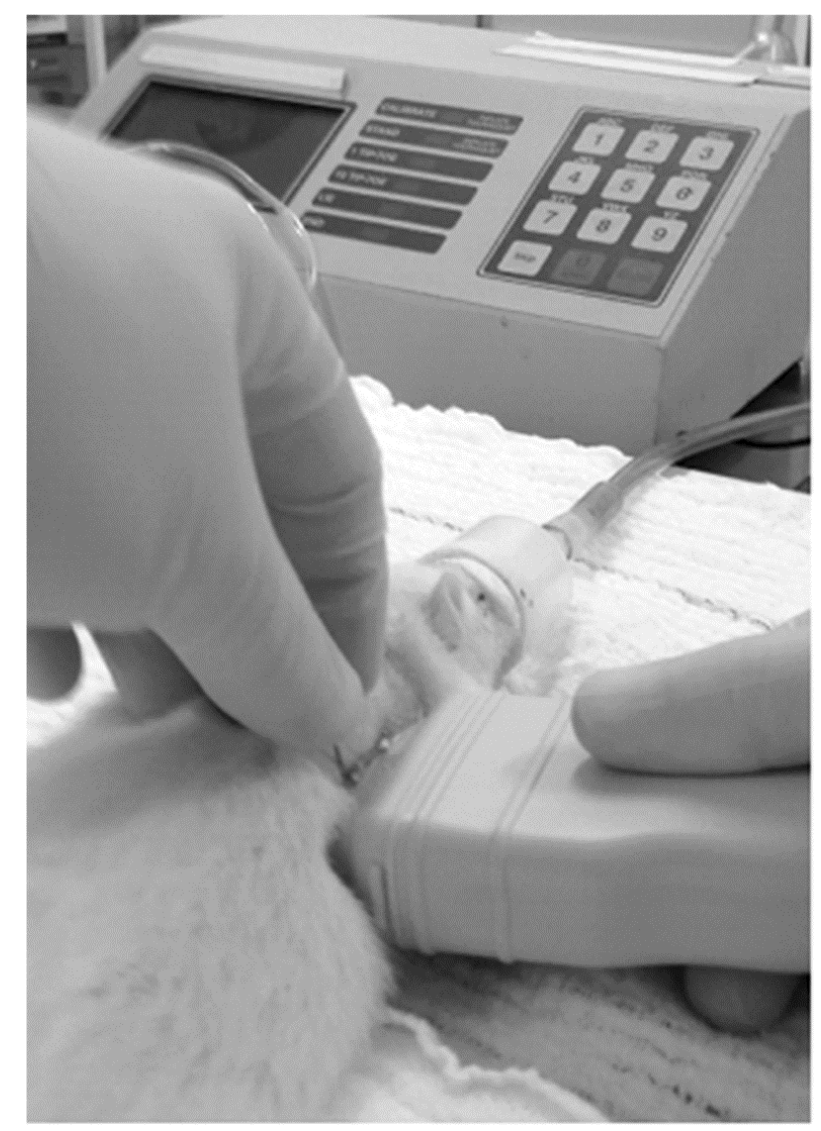

Figure 1 - Ultrasound used to guide thoracentesis.

Pleural fluid samples stored at $-80^{\circ} \mathrm{C}$ were thawed in room temperature and shaken gently for determination of TGF-ß1 levels using an ABCAM ab119558 TGF beta 1 Rat ELISA Kit, following manufacturer instructions. All analyses were performed in duplicate.

\section{Statistical analysis}

Data were stored in a Microsoft Excel 2008 spreadsheet and analyzed in SPSS 20. Continuous variables were expressed as mean \pm standard deviation (SD) or median (interquartile range). Categorical variables were expressed as absolute and relative frequency. Significance was established at $5 \%$ $(p<0.05)$. Longitudinal data were analyzed using generalized estimating equations.

\section{Results}

The mean volume of fluid samples was $1.2 \mathrm{~mL}$, with no statistical difference between the groups. Gram staining revealed Staphylococcus aureus in all animals in the SA Group ( $\mathrm{n}=17$ ) and Streptococcus pneumoniae in all animals in the SP Group $(n=12)$. No germs were detected in control animals.

Two SA animals and one SP animal died before $12 \mathrm{~h}$ and were excluded from the analysis. The deaths were due to hemopneumothorax and infection (SA group) or infection (SP group). Therefore, 15 SA and $11 \mathrm{SP}$ and animals were studied. Also, three SA animals and five SP animals died before 24 h. There were no deaths in the control group, but one control animal did not develop pleural fluid. The levels of protein, glucose, and LDH in pleural fluid $12 \mathrm{~h}$ after injection of bacteria or turpentine are described in Table 1. 
Table 1 - Comparison between mean levels of proteins, LDH and glucose 12 hours after bacterial or turpentine inoculation in pleural space in a rat model.

\begin{tabular}{lcccc}
\hline Variables & $\begin{array}{c}\text { SA group }(\mathbf{n = 1 5}) \\
\text { Mean }(95 \% \mathrm{Cl})\end{array}$ & $\begin{array}{c}\text { SP group }(\mathbf{n = 1 1 )} \\
\text { Mean }(95 \% \mathrm{CI})\end{array}$ & $\begin{array}{c}\text { Control group }(\mathbf{n = 9 )} \\
\text { Mean }(95 \% \mathrm{CI})\end{array}$ & $\mathbf{p}$ \\
\hline Protein $(\mathrm{mg} / \mathrm{dL})$ & 5.454 & 6.00 & 4.778 & $<0.001^{1}$ \\
& $(5.190-5.717)$ & $(5.412-6.588)$ & $(4.445-5.11)$ & \\
Glucose $(\mathrm{mg} / \mathrm{dL})$ & 106.36 & 14.50 & 160.78 & $<0.001^{2}$ \\
& $(92.74-119.97)$ & $(-17$ to 44.06$)$ & $(138.97-182.59)$ & \\
LDH (U/L) & 8067.71 & 4663.25 & 20709.11 & $<0.001^{3}$ \\
\hline
\end{tabular}

SA, Staphylococcus aureus; SP, Streptococcus pneumoniae; $\mathrm{Cl}$, confidence interval; LDH, lactate dehydrogenase.

${ }^{1}$ Control group differs from both SA $(p=0.015)$ and SP groups $(p<0.001$, Dunnett's T3 test), but no difference was detected between SA and SP groups ( $p=0.197$, Dunnett's T3 test).

${ }^{2}$ Statistically significant difference (Dunnett's T3 test) for all intergroup comparisons $(p<0.001)$.

${ }^{3}$ Control group differs from both SA $(p=0.015)$ and SP groups $(p<0.001$, Dunnett's T3 test), but no difference was detected between SA and SP groups ( $p=0.098$, Dunnett's T3 test).

Table 2 shows the mean levels of TGF-ß1 at each time point. TGF-ß1 levels are not available for SP animals at $36 \mathrm{~h}$ because all animals died before this time point. No differences were observed in TGF-ß1 levels between the groups ( $p=0.12$ ). Significant intragroup decreases in TGF-ß1 levels were observed between 12 and $24 \mathrm{~h}$ after bacterial inoculation $(p<0.01)$.

Table 2 - Mean levels of TGF-ß1 at each time point in a rat model of empyema.

\begin{tabular}{|c|c|c|c|}
\hline \multirow{2}{*}{ Group } & \multicolumn{3}{|c|}{ Mean levels of TGF-ß1 in pg/mL (95\%Cl) } \\
\hline & $12 \mathrm{~h}$ (baseline) & $24 \mathrm{~h}$ & $36 \mathrm{~h}$ \\
\hline Staphylococcus aureus & $\begin{array}{l}5.3450 \\
(5.3449-5.3451)\end{array}$ & $\begin{array}{l}4.6700 \\
(4.6699-4.6700)\end{array}$ & $\begin{array}{l}4.6699 \\
(4.6699-4.6700)\end{array}$ \\
\hline Streptococcus pneumoniae & $\begin{array}{l}5.3449 \\
(5.3449-5.3450)\end{array}$ & $\begin{array}{l}4.6700 \\
(4.6699-4.6701)\end{array}$ & - \\
\hline Control & $\begin{array}{l}5.3450 \\
(5.3949-5.3451)\end{array}$ & $\begin{array}{l}4.6700 \\
(4.6700-4.6702)\end{array}$ & $\begin{array}{l}4.669 \\
(4.6699-4.6702)\end{array}$ \\
\hline
\end{tabular}

TGF-ß1, transforming growth factor beta $1 ; \mathrm{Cl}$, confidence interval.

\section{Discussion}

TGF exists in five isoforms, but only three, ß-1, ß-2, and ß-3, which present similar biochemical behavior, are found in mammals 5 . This cytokine is produced by mesothelial cells, alveolar macrophages, and inflammatory cells in pleural fluid ${ }^{12,14}$. TGF- $\beta$ acts by stimulating fibrinolysis through the reduction of tissue plasminogen activators caused by increased production of plasminogen activator inhibitors. An additional role of TGF-ß involves the production of extracellular matrix, collagen, laminin, and fibronectin, in addition to the attraction of fibroblasts, which stimulates the synthesis and deposition of matrix components ${ }^{14}$. TGF- $ß$ also has immunomodulatory activity, since it induces immune suppression in lymphocytes. Because of this negative regulation of fibrinolytic 
activity, TGF- $ß$ has been associated with transformation of free-flowing pleural effusion into multiloculated effusion ${ }^{1,15}$.

The first cytokine studies using animal models of pleural effusion were carried out in the late 1980s. In the early 2000s, several experimental studies $s^{6-8,10,16-18}$ were conducted to correlate the presence of cytokines in pleural fluid with early detection of empyema or its associated complications. The need to use a low-cost, more accessible and reproducible alternative led us to select and adapt a previously developed rat model ${ }^{11,12}$ to evaluate the levels of TGF-ß1 at different moments after induction of pleural effusion.

Our study showed the mean levels of TGF-ß1 at each time point were not different among all experiment and control groups. However, we observed a significant decrease in TGF- $\$ 1$ levels between 12 and $24 \mathrm{~h}$ after bacterial inoculation. These results do not support previous studies in rabbits ${ }^{19}$, which report progressive increase of TGF- $\$ 1$ in the pleural fluid of animals, directly proportional to the time elapsed since inoculation of bacteria into the pleural space. However, mean TGF-ß1 concentration in the turpentine group were similar to that observed in the infected pleural effusion groups. This was also observed in other previous studies ${ }^{1,4,6}$, proving that increased TGF-ß1 levels can occur even in noninfected pleural effusion, possibly as a reaction to pleural inflammation.

Even though the use of turpentine to induce an inflammatory response is not new, this chemical irritant had never been used to induce sterile pleural effusion in rats. Animals that received turpentine injection developed large-volume pleural effusion. In the present study, this allowed us to compare different types of intrapleural exudate (sterile or infected produced by bacteria) by measuring LDH and protein levels. Because inoculation of turpentine caused major pain in the animals, inducing antalgic posture and gait as well as major tachypnea, tramadol was added to the management protocol, with adequate control of pain.

The literature ${ }^{18,20}$ describes loss of experimental animals ranging from $22 \%$ to $35 \%$. Thus, the $25 \%$ loss recorded in the present study was consistent with the reported rates.

The present study has introduced innovations to the traditional technique of empyema induction in rats. For example, we used US to diagnose free-flowing or multiloculated effusion and guide thoracentesis. Another innovation of this study is the intra-animal comparison of TGF-ß1 levels at different time points using repeat US-guided thoracentesis to increase the accuracy and efficacy of the tap procedure and minimize the risk of pneumothorax or no fluid return. This technique was tested for the first time in the present animal model, showing the feasibility of using the same individual to detect changes at different time points and produce intraanimal comparisons. As a result, the number of animals required for the experiment was also much lower (decrease of one third).

Some limitations of this study must be addressed. Because no previous studies using rat models for dosing of TGF-ß1 were available, we were not able to calculate the sample size. The number of animals was defined based on previous work with rat models of empyema focusing on other aspects. The TGF- 11 values observed in our study were very similar regardless of treatment, which suggests that future studies should determine a more sensitive method to measure TGF-ß1 levels, which is not yet available.

\section{Conclusion}

Transforming growth factor beta 1 levels were not important for the diagnosis of CPPE or empyema, because there was similar 
TGF-ß1 concentration in both infected and sterile pleural fluids, and TGF-ß1 levels did not increase at different time points after induction of pleural effusion.

\section{References}

1. Duysinx BC, Corhay JL, Hubin L, Nguyen $D$, Henket $M$, Louis R. Diagnostic value of interleukine-6, transforming growth factorbeta 1 and vascular endothelial growth factor in malignant pleural effusions. Respir Med. 2008;102(12):1708-14. doi: 10.1016/j. rmed.2008.07.008.

2. Fraga JC, Kim P. Surgical treatment of parapneumonic pleural effusion and its complications. J Pediatr (Rio J). 2002;78(Suppl 2):S161-70. doi: 10.1590/ S0021-75572002000800007.

3. Lau CT, Fung CH, Wong KK, Tam P. Timely thoracoscopic decortication promotes the recovery of paediatric parapneumonic empyema. Pediatr Surg Int. 2015;31(7):66570. doi: 10.1007/s00383-015-3723-y.

4. Ceyhan BB, Demiralp E, Karakurt ZL, Karakurt $S$, Sungur $M$. Transforming growth factor beta-1 level in pleural effusion. Respirology. 2003;8(3):321-5. doi: 10.1046/j.14401843.2003.00474.x.

5. Sasse SA, Jadus MR, Kukes GD. Pleural fluid transforming growth factorbeta1 correlates with pleural fibrosis in experimental empyema. Am J Respir Crit Care Med. 2003;168(6):700-5. doi: 10.1164/ rccm.2202043.

6. Allen SS, Cassone L, Lasco TM, McMurray DN. Effect of neutralizing transforming growth factor beta1 on the immune response against Mycobacterium tuberculosis in guinea pigs. Infect Immun. 2004;72(3):135863. doi: 10.1128/IAI.72.3.1358-1363.2004.

7. Giamarellos-Bourboulis EJ, Tzepi I, Tsovolou I, Spyridaki A, Tsaganos T, Vaki I, Kotsaki A, Polychronopoulos V. Impact of multidrug resistance on experimental empyema by Pseudomonas aeruginosa. Respiration. 2011;82(1):46-53. doi: 10.1159/000326893.

8. Lee YC, Devin CJ, Teixeira LR, Rogers JT, Thompson PJ, Lane KB, Light RW. Transforming growth factor beta2 induced pleurodesis is not inhibited by corticosteroids. Thorax. 2001;56(8):643-8. doi: 10.1136/thorax.56.8.643.

9. Elemraid MA, Thomas MF, Blain AP, Rushton SP, Spencer DA, Gennery AR, Clark JE. Risk factors for the development of pleural empyema in children. Pediatr Pulmonol. 2015;50(7):721-6. doi: 10.1002/ppul.23041.

10.Opitz I, Arni S, Oberreiter B, Asmis LM, Vogt $P$, Rousson V, Weder W, Lardinois D. Perioperative diclofenac application during video-assisted thoracic surgery pleurodesis modulates early inflammatory and fibrinolytic processes in an experimental model. Eur Surg Res. 2013;50(1):14-23. doi: 10.1159/000341670.

11.Fraga JC, Amantea S, Argenta R, Moura L, Nhuch C, Borowski S. Experimental empyema in rats through intrapleural injection of bacteria. J Pediatr (Rio J). 2001;77(6):469-74. doi: 10.1590/S002175572001000600009.

12.Schopf LF, Fraga JC, Amantea SL, Sanches P, Muller A, Borowski S, Kulczynski J, Costa E. Induction of pleural empyema in rats by thoracentesis with intrapleural pressure monitoring. Pediatr Surg Int. 2004;20(7):5159. doi: 10.1007/s00383-004-1227-2.

13. Brasil. Presidência da República. Lei no 11.794, de 8 de outubro de 2008. Regulamenta o inciso VII do $\S 10$ do art. 225 da Constituição Federal, estabelecendo procedimentos para o uso científico de animais; revoga a Lei no 6.638, de 8 de maio de 1979; e dá outras providências. Available from: http://www. planalto.gov.br/ ccivil_03/_ato2007-2010/2008/lei/l11794. htm

14. Mutsaers SE, Prele CM, Brody AR, Idell S. Pathogenesis of pleural fibrosis. Respirology. 2004;9(4):428-40. doi: 10.1111/j.14401843.2004.00633.x.

15.Chiu CY, Wong KS, Huang JL, Tasi MH, Lin TY, Hsieh SY. Proinflammatory cytokines, fibrinolytic system enzymes, and biochemical indices in children with infectious para-pneumonic effusions. Pediatr Infect Dis J. 2008;27(8):699-703. doi: 10.1097/INF.0b013e318170b678.

16. Marchi E, Vargas FS, Takemura RL, Acencio $M M$, Antonangelo L, Teixeira LR, Light RW. Monoclonal antibodies anti-TGFbeta1 and anti-VEGF inhibit the experimental pleurodesis induced by silver nitrate. Growth Factors. 2012;30(5):304-9. doi: 
10.3109/08977194.2012.721359.

17.Saroglou M, Ismailos G, Tryfon S, Liapakis I, Papalois A, Bouros D. Penetration of azithromycin in experimental pleural empyema fluid. Eur J Pharmacol. 2010;626(2-3):271-5. doi: 10.1016/j. ejphar.2009.10.027.

18.Sasse SA, Causing LA, Mulligan ME, Light RW. Serial pleural fluid analysis in a new experimental model of empyema. Chest. 1996;109(4):1043-8. doi: 10.1378/ chest.109.4.1043.

19.Kunz CR, Jadus MR, Kukes GD, Kramer F, Nguyen VN, Sasse SA. Intrapleural injection of transforming growth factor-beta antibody inhibits pleural fibrosis in empyema. Chest. 2004;126(5):1636-44. doi: 10.1378/ chest.126.5.1636.
20.Genofre EH, Vargas FS. Experimental empyema in rats through intrapleural injection of bacteria. J Pediatr (Rio J). 2001;77(6):439-40. doi: 10.1590/S002175572001000600004 .

\section{- Acknowledgements}

To Experimental Animal Unit, Hospital de Clínicas de Porto Alegre, and to nurse Marta J. Giotti Cioato, veterinarians Fabíola Schons Meyer and Tuane Nerissa Alves Garcez, and biologists Fernanda Pereira and Patrícia Khoeler for their assistance with the experimental protocol.

\section{Correspondence:}

Jose Carlos Fraga

Rua Ramiro Barcelos, 2350/600

90035-903 Porto Alegre - RS Brasil

Tel.: (55 51)3359-8232

fraga.jcs@gmail.com

Received: Oct 26, 2017

Review: Dec 27, 2017

Accepted: Jan 29, 2018
Conflict of interest: none

Financial source: none

${ }^{1}$ Research performed at Experimental Research Center, and Division of Thoracic Pediatric Surgery, Service of Pediatric Surgery, Hospital de Clínicas of Porto Alegre (HCPA), School of Medicine, Universidade Federal do Rio Grande do Sul (UFRGS). Part of Master degree thesis, Postgraduate Program in Medicine, UFRGS. Tutor: Prof. José Carlos Fraga. 